\title{
METODE ECONOMIC PRODUCTION QUANTITY DALAM SISTEM PERENCANAAN DAN PENGALIHAN PRODUKSI
}

\author{
Yoga Prastya ${ }^{1)}$, Tri Irawati ${ }^{2)}$, Bambang Satrio Nugroho ${ }^{3)}$ \\ 1)3) Program Studi Sistem Informasi, STMIK Sinar Nusantara Surakarta \\ ${ }^{2)}$ Program Studi Komputerisasi Akuntansi, STMIK Sinar Nusanatra Surakarta \\ 1)yoga.prastyapersis@gmail.com, ${ }^{2)}$ 3irawati@sinus.ac.id, ${ }^{3)}$ bambangsn08@gmail.com
}

\begin{abstract}
Over Production and developing modes require companies to issue new products before the old product is sold out. The company problem is that the company loses and many products are damaged so the product cannot be sold because the product is stored too long and the storage costs and selling value fall product because of similar product competition. The product control phase began to be implemented to anticipate the swelling of new inventories, with the method of economic production quantity being one of the efforts to suppress production and control production so that the value of these products could be maintained and the company would not suffer losses due to damage to manufactured goods. The purpose of this study is to find out the economical ordering value (EOQ) and the optimal amount of production (EPQ). Data analysis by analyzing the system using UML, input output design and system testing From another process, one form of a separate data collection process is provided according to the production data control needs of the EPQ Method and is feasible if the process is stored in full. And the data displayed is in accordance with the testing of Production control validity and the results of the test can be concluded that the software built is free of syntax errors for results that are as expected. All functions in the production control application with the Algorithm method can be valid.
\end{abstract}

Keywords: Production Control, Economical Ordering Value, Economic Production Quantity

\section{PENDAHULUAN}

Berkembangnya industri garment dunia tentu sangat berpengaruh bagi bangsa Indonesia, dimana begitu banyaknya jenis dari berbagai macam merk terus menyemarakkan pasar di Indonesia. Penurunan daya beli masyarakat menjadi masalah bagi perusahaan semakin membengkaknya persediaan produk tersebut. Masalah yang dialami perusahaan adalah perusahaan menjadi rugi dan banyak produk yang rusak sehingga produk tidak dapat terjual karena produk terlalu lama disimpan serta membengkaknya biaya penyimpanan dan jatuhnya nilai jual produk karena persaingan produk yang sejenis.

Berkembangnya industri garment dunia tentu sangat berpengaruh bagi bangsa Indonesia, dimana begitu banyaknya jenis dari berbagai macam merek terus menyemarakan pasar di Indonesia. Melihat Indonesia merupakan pasar yang cukup potensial. Hal ini menjadi peluang bagi para pelaku industry garment di Indonesia untuk dapat memanfaatkan kesempatan ini. Akan tetapi penurunan daya beli masyarakat menjadi bumerang bagi perusahaan dengan semakin membengkaknya persediaan produk tersebut.
Tahap pengendalian produk dilakukan pada saat dimulainya produksi untuk mengantipasi membengkaknya persediaan baru, dengan metode Economic Production Quantity (EPQ) merupakan salah satu upaya menekan produksi dan mengendalikan produksi sehingga nilai produk tersebut dapat dijaga dan perusahaan tidak akan mengalami kerugian yang dikarenakan rusaknya barang produksi.

Adapun perumusan masalah yang akan diungkapkan penulis adalah "Sistem Perencanaan Dan Pengendalian Produksi Metode Economic Production Quantity Pada Pt. Indo Garment". Tujuan dari penelitian ini membuat perancangan pengendalian produksi dengan metode EPQ agar bisa diaplikasikan sebagai pembantu penekanan kerugian di PT. Indo Garment.

\section{TINJAUAN PUSTAKA}

\subsection{Economic production quantity (EPQ)}

EPQ adalah sejumlah kuantitas produk yang harus diproduksi atau pun dipesan dalam ukuran lot tunggal untuk dapat meminimumkan total biaya yang mencakup biaya setup dan inventory holding cost. EPQ merupakan 
pengembangan model persediaan dengan mempertimbangkan adanya laju produksi atau laju kedatangan barang secara uniform atau seragam yang biasanya terjadi di dalam sistem manufaktur di mana hasil produksi suatu stasiun kerja akan menjadi masukkan bagi stasiun kerja yang lain [1].

Untuk menghitung besarnya nilai EPQ terlebih dahulu harus mengetahui nilai Ecomic Order Quantity (EOQ). Adapun rumus EOQ adalah

$$
E O Q=\sqrt{\frac{2 S D}{H}}
$$

Keterangan :

EOQ : jumlah pemesanan ekonomis.

$S \quad$ : biaya pemesanan setiap kali pesan.

D : penggunaan bahan baku pertahun.

$\mathrm{H}$ : biaya penyimpanan per-unit.

Dalam EOQ yang berurutan dalam suatu tahun maka akan dihitung nilai ekonomis dengan adanya siklus pemesanan ulang $(F)$, dapaun formula untuk pemesanan ualng adalah:

$$
F=\frac{D}{E O Q}
$$

Keterangan :

F : siklus pemesana ulang dalam periode

D : Jumlah Produksi dalam periode yang dihitung

EOQ : Jumlah pemesanan ekonomis

Sedangkan nilai EPQ dihitung dengan menggunakan rumus :

$E P Q=\sqrt{\frac{2 D S c P}{H c(p-d)}}$

Keterangan :

EPQ : Jumlah Produksi optimal

D : Jumlah Produksi dalam periode yang dihitung

Sc : Biaya Pengadaan

$\mathrm{P} \quad$ : Produksi periode akhir

$\mathrm{Hc}$ : Biaya Penyimpanan

p : Biaya rata-rata produksi

d : rata-rata nilai penjualan

berdasarkan hasil EPQ tersebut kemudian dihitung nilai maksimal pada tahun pertama / tahun dasar menggunakan rumus :

$$
\operatorname{Imax}=E P Q\left(1-\frac{d}{p}\right)
$$

Sedangkan untuk tahun berikutnya maka imax dibuat secara rata-rata yaitu dengan rumus :

$$
\operatorname{Imax}=[(\operatorname{imax} n-1)+(\operatorname{imax} n)] / 2---(5)
$$

\subsection{Pemanfaatan EPQ}

Penyimpanan persediaan dalam jangka waktu yang lama akan berdampak pada keusangan dan menurunnya kualitas, sehingga diperlukan perhitungan jumlah persediaan yang optimal. Model persediaan Economic Production Quantity (EPQ) merupakan suatu metode yang digunakan untuk mempertimbangkan jumlah produksi dan jumlah permintaan hasil produksi [2].

\subsection{Penelitian terdahulu}

Model Economic Production Quality (EPQ) mengarahkan perusahaan agar dapat meminimalkan total biaya produksi dengan mereduksi biaya inventori. Parameter model dasar EPQ adalah demand, biaya setup mesin dan biaya simpan persediaan. Namun dalam kenyataanya perusahaan tidak hanya memiliki demand yang bersifat kontinu, namun sering kali terjadi demand diskrit yang pemenuhannya dilakukan dalam suatu rentang waktu tertentu. Begitu pula halnya dengan UD. Sanda sebagai produsen kerupuk ikan khas Kalimantan Timur, dalam pemenuhan kebutuhan konsumen terdiri dari 2 tipe demand. Penelitian ini menggunakan metode kuantitatif. Dari peninjauan jumlah permintaan dan perhitungan terhadap tingkat persediaan, diperoleh waktu siklus pengiriman optimal adalah 2 kali dan biaya rata-rata satu periode adalah Rp. 3.336.750,- serta biaya total sebesar Rp. 6.673.500,-[2]

Pada perusahaan manufaktur tidak adanya pengendalian persediaan baik untuk bahan baku maupun barang jadi dapat menimbulkan kemungkinan kerugian yang akan dialami oleh perusahaan tersebut. Hal itu dapat terjadi, dikarenakan terdapat penumpukan bahan baku maupun barang jadi. Oleh karena itu, diperlukan sebuah aplikasi untuk melakukan pengendalian persediaan. Metode yang dapat digunakan dalam pengendalian persediaan pada perusahaan tersebut adalah dengan menggunakan metode Economic Production Quantity (EPQ). Metode 
ini dapat menghasilkan jumlah pesanan produksi, frekuensi produksi per tahun dan total biaya minimal yang harus dikeluarkan oleh perusahaan. Pada aplikasi ini menyajikan catatan akuntansi berupa laporan pembelian, laporan biaya, jurnal umum, dan buku besar. Aplikasi ini dibuat berbasis web dengan menggunakan bahasa pemrograman PHP dan database MYSQL. Hasil akhir dari penelitian ini akan menghasilkan aplikasi yang dapat menghasilkan jumlah pesanan produksi.[3]

Peramalan yang tepat untuk Box Speaker 6 inch, Box Speaker 8 inch dan Box Speaker 10 inch adalah Winters' Method, dan untuk Box Speaker 12 inch adalah Quadratic. Dan hasil dari perhitungan dengan metode EPQ menggunakan data hasil peramalan setiap metode produk yaitu didapatkan bahwa jumlah siklus optimal produksi sebanyak 8 siklus produksi, dimana 1 siklus produksi selama 36 hari, dan pembagian pergantian produksi setiap item dalam 1 siklus produksi yaitu produksi box speaker 6 inch $=9$ hari harus memproduksi sebanyak 5971 box, produksi box speaker 8 inch $=10$ hari harus memproduksi sebanyak 5649 box, produksi box speaker 10 inch $=9$ hari harus memproduksi sebanyak 3872 box, dan produksi box speaker 12 inch $=5$ hari harus memproduksi sebanyak 2113 box. Dari perhitungan menggunakan metode EPQ terjadi penghematan biaya produksi dan otomatis meningkatkan laba perusahaan sebesar $11 \%$ atau sebesar Rp. 3.070.519.227, sehingga metode perusahaan tidak optimal dalam produksi nya dan dapat menerapkan metode EPQ ini.[4]

\section{METODE PENELITIAN}

\subsection{Pengambilan Data}

\section{a. Metode Observasi}

Mengetahui proses-proses yang terjadi di perusahaan dan data yang diperoleh tentang data produksi, tahun 2014, jenis produksi dan bagaimana pengambilan keputusan pengendalian produksi.

b. Metode Wawancara

Menanyakan berupa kondisi - kondisi produksi yang ditangani, perkembangan penjualan di wilayah perusahaan, penanganan yang dibutuhkan untuk pengendalian produksi. c. Metode Kepustakaan

Mengumpulkan data dan informasi serta pengetahuan yang berasal dari buku mengenai metode EPQ dan buku pembahasan pengendalian produksi, semua informasi tentang produksi dan sirkulasinya.

\subsection{Analisa Sistem}

Analisa ini dilakukan untuk mengetahui apa saja kebutuhan yang dibutuhkan untuk merancang program untuk menentukan pengendalian produksi dan bagaimana kerja dari program yang dirancang seperti kerja dari input, proses, dan outputnya. Sehingga sistem $E P Q$ yang di rancang menjadi efektif dan efesien dalam pengimplementasiannya nanti. Penulis akan membuat aplikasi sistem penunjang keputusan pengendalian produksi dengan metode EPQ yang terdiri dari :

a. Data master yaitu data produk dan Data produksi.

b. Pengolahan dengan metode EPQ.

c. Laporan-laporan yang dibutuhkan.

\subsection{Perancangan sistem}

UML merupakan bahasa pemodelan standar yang dimiliki sintak dan semantik Unified Modeling Language (UML) adalah sebuah bahasa pemodelan yang digunakan untuk menentukan atau mendeskripsikan sebuah sistem software berdasarkan objekobjek yang ada di sistem tersebut. UML tidak menentukan metode apa yang harus digunakan dalam mengembangkan suatu sistem, namun hanya menentukan notasinotasi standar yang biasa digunakan untuk object modeling.[5]

UML juga merupakan bahasa pemodelan untuk sistem atau perangkat lunak yang berparadigma (berorientasi objek), digunakan untuk menyederhanakan permasalahan yang komplek sehingga lebih mudah dipelajari dan dipahami. [6]

\section{a. Use Case Diagram}

Use case diagram digunakan untuk menggambarkan interaksi antara pengguna sistem (actor) atau pengguna data yaitu bagian penjualan dan pimpinan dengan kasus (use case) data yang diolah seperti pendataan persediaan, proses penjualan dan penerapan pengendalian produksi yang disesuaikan dengan langkah - langkah (scenario) yang telah ditentukan. Use Case adalah suatu pola atau gambaran yang menunjukkan kelakukan atau kebiasaan sistem. Use Case Diagram dibuat untuk memvisualisasikan/ menggambarkan hubungan antara Actor dan Use Case. Use Case diagram mempresentasikan kegunaan atau fungsifungsi sistem dari perspektif pengguna. Use case yang dibuat berupa use case data produk, data produksi, use case perhitungan dengan $E P Q$. 


\section{b. Class Diagram}

Class diagram adalah sebuah class yang menggambarkan struktur dan penjelasan class, paket, dan objek serta hubungan satu sama lain seperti containment, pewarisan, asosiasi, dan lain-lain. Class juga memiliki 3 area pokok (utama) yaitu : nama, atribut, dan operasi. Nama berfungsi untuk member identitas pada sebuah kelas, atribut fungsinya adalah untuk member karakteristik pada data yang dimiliki suatu objek di dalam kelas, sedangkan operasi fungsinya adalah memberikan sebuah fungsi ke sebuah objek. Class diagram yang dibuat berupa class diagram proses data produk, class diagram proses data produksi, class diagram proses perhitungan dengan EPQ.

\section{c. Activity Diagram}

Activity diagram Menggambarkan aktifitas - aktifitas, objek, state, transisi state dan event. Activity diagram adalah kegiatan diagram alur kerja yang menggambarkan perilaku sistem untuk aktivitas. Activity diagram yang dibuat berupa Activity diagram data produk, Activity diagram data produksi, Activity diagram perhitungan dengan EPQ.

\section{d. Sequence Diagram}

Sequence Diagram menjelaskan secara detail tentang urutan proses yang dilakukan dalam sistem untuk mencapai tujuan dari use case. Sequence diagram tersusun dari elemen obyek, interaction dan message. Interaction menghubungkan 2 obyek dengan pesannya. Diagram ini menjelaskan aspek dinamis dari sistem yang sedang dibangun. Diagram yang dibuat berupa diagram data produk, diagram data produksi, diagram perhitungan dengan EPQ.

\section{e. Component Diagram}

Component Diagram adalah diagram yang menggambarkan sistem pada perangkat lunak yang dipecah menjadi bentuk struktur komponen-komponen yang saling ketergantungan satu dengan komponen lainnya. Component diagram menggambarkan struktur fisik dari kode, pemetaan pandangan logis dari kelas proyek untuk kode aktual di mana logika ini dilaksanakan. Diagram yang dibuat berupa diagram data produk, diagram data produksi, diagram perhitungan dengan $E P Q$

\section{f. Desain Database}

Desain ini mengulas tabel penyimpanan yang digunakan beserta nama field dan panjang field. Desain ini juga menjabarkan penggunaan index dan kapasitas yang diperlukan. database yang dibuat berupa database data produk, database data produksi, database perhitungan dengan EPQ

\subsection{Implementasi Sistem}

Implementasi ini dilakukan untuk mengetahui spesifikasi komputer untuk menjalankan program dan program apa saja yang di butuhkan. Merupakan tahap penelitian yang dilakukan untuk mempraktekkan langsung hasil dari analisa yang bertujuan untuk menguji kebenaran sistem yang dirancang mulai dari input master data produk, master data produksi, pengolahan data perhitungan dengan EPQ, dan output laporan data. Software yang dipakai yaitu Visual Basic Net dengan database Sql Server.

\subsection{Pengujian Sistem}

Proses selanjutnya adalah pengujian program, program yang telah dibangun akan diuji untuk mengetahui apakah program tersebut berjalan dengan benar dan sesuai dengan perancangan yang dilakukan. Setelah program selesai maka tahap selanjutnya adalah tahapan pemeliharaan. Untuk pengujian aplikasi ini menggunakan cara aplikasi langsung mendata data langsung dari kondisi produksi yang dilakukan. White box testing adalah pengujian yang didasarkan pada pengecekan terhadap detail perancangan, menggunakan struktur kontrol dari desain program secara prosedural untuk membagi pengujian ke dalam beberapa kasus pengujian. Secara sekilas dapat diambil kesimpulan white box testing merupakan petunjuk untuk mendapatkan program yang benar secara $100 \%$. Pengujian program digunakan untuk mengetahui Sistem Pendukung Keputusan valid atau tidak. Pengujian validitas program dilakukan dengan membandingkan hasil perhitungan Sistem Pendukung Keputusan dengan hasil perhitungan manual berdasarkan perhitungan dengan Aplikasi diperoleh dari Implementasi program yang telah dibuat. Sehingga dapat diketahui tingkat akurasi Sistem Pendukung Keputusan.

\section{IV.HASIL DAN PEMBAHASAN}

\subsection{Studi Kasus}

Penelitian ini dilakukan dengan pengumpulan data di PT. Indogarmen, datadata tersebut disajikan pada Tabel 1 dan Tabel 2. 
Tabel 1: Data Produksi dan penjualan (D)

\begin{tabular}{|c|c|c|c|c|}
\hline \multirow{2}{*}{ Bulan } & \multicolumn{2}{|l|}{ Produksi } & \multicolumn{2}{|l|}{ Penjualan } \\
\hline & 2011 & 2012 & 2011 & 2012 \\
\hline Januari & $30.524,84$ & $37.780,90$ & $29.386,26$ & $37.211,54$ \\
\hline Februari & $34.164,29$ & $41.498,79$ & $33.534,18$ & $40.570,15$ \\
\hline Maret & $80.016,80$ & $47.030,47$ & $79.577,56$ & $46.149,31$ \\
\hline April & $53.447,52$ & $45.854,56$ & $53.313,27$ & $45.236,87$ \\
\hline Mei & $53.777,58$ & $46.864,44$ & $53.698,28$ & $46.649,14$ \\
\hline Juni & $30.985,92$ & $50.590,04$ & $30.500,00$ & $50.342,99$ \\
\hline Juli & $62.924,24$ & $54.456,13$ & $62.415,99$ & $54.236,62$ \\
\hline Agustus & $54.680,93$ & $45.990,05$ & $54.448,80$ & $44.968,89$ \\
\hline September & $45.698,24$ & $55.057,53$ & $45.439,90$ & $54.003,75$ \\
\hline Oktober & $46.402,01$ & $55.768,88$ & $45.754,37$ & $55.429,92$ \\
\hline Nopember & $45.193,27$ & $54.772,16$ & $44.599,31$ & $54.705,33$ \\
\hline Desember & $48.876,79$ & $53.134,60$ & $48.873,94$ & $52.559,74$ \\
\hline Jumlah & $586.692,42$ & $588.798,54$ & $581.541,87(\mathrm{D})$ & $582.064,25$ \\
\hline Rata rata & $48.891,035(p)$ & $49.066,545$ & $48.461,822(d)$ & $48.505,354$ \\
\hline
\end{tabular}

Sumber : data produksi dan penjualan 2011-2012 PT Indo Garment (dalam Rupiah)

Tabel 2. Data Biaya Pemesanan, Biaya Penyimpanan, dan Biaya Pengadaan

\begin{tabular}{|l|c|c|c|c|}
\hline Tahun & $\begin{array}{c}\text { Biaya } \\
\text { Pemesanan } \\
(\mathrm{OC})\end{array}$ & $\begin{array}{c}\text { Benyimpanan } \\
(\mathrm{HC})\end{array}$ & $\begin{array}{c}\text { Biaya } \\
\text { Pengadaan (SC) }\end{array}$ & $\begin{array}{c}\text { Harga } \\
(\mathrm{P})\end{array}$ \\
\hline 2011 & $13.203 .729,711$ & $11.860 .666,197$ & $34.788 .738,577$ & 75.639 \\
\hline 2012 & $13.832 .649,728$ & $13.522 .724,281$ & $38.155 .309,780$ & 74.343 \\
\hline Jumlah & $27.036 .379,439$ & $25.383 .390,478$ & $72.944 .048,357$ & \\
\hline
\end{tabular}

Sumber. PT Indo Garment

Berdasarkan data yang telah ada maka diperoleh :

1. Jumlah kebutuhan garmen dalam satu tahun (Tahun 2011: D = Rp. 581.541,867 dan Tahun 2012 : D = Rp. 582.064,252)

2. Biaya pemesanan garmen (Tahun 2011 : Oc $=\operatorname{Rp} 13.203 .729,711$ danTahun $2012:$ Oc $=\operatorname{Rp~13.832.649,728)~}$

3. Biaya penyimpanan garmen (Tahun 2011 : $\mathrm{Hc}=\mathrm{Rp}$ 11.860.666,197 danTahun $2012:$ $\mathrm{Hc}=\mathrm{Rp} 13.522 .725,281)$

4. Harga garmen per ( Tahun $2011: P=R p$ 75.639 dan tahun $2012: P=R p$ 74.343)

5. Laju produksi (Tahun $2011: p=48.891,035$ dan Tahun $2012: p=49.066,545$ )

6. Laju permintaan (Tahun 2011 : $\mathrm{d}=$ 48.461,822 dan Tahun $2012: d=$ $48.505,354)$

Perhitungan Jumlah Pemesanan Ekonomis dengan EOQ ( Economi Order Quantity )
Jumlah pemesanan ekonomis (EOQ) garmen pada tahun 2011 untuk setiapkali pesan diperoleh dengan menggunakan rumus 1 :

$$
\begin{aligned}
& E O Q=\sqrt{\frac{2(581.541,867)(13.203 .729,711)}{11.860 .666,197}} \\
& E O Q=1.137,887(1.137 / \text { pesan })
\end{aligned}
$$

Jadi, siklus pemesanan ulang garmen pada tahun 2011 dengan model EOQ menggunakan rumus 2 :

$$
\begin{aligned}
\mathrm{F} & =\frac{D}{E O Q}=\frac{581.541,867}{1.137,887} \\
& =511,072(512 \mathrm{kali} / \text { tahun })
\end{aligned}
$$

Jumlah pemesanan ekonomis (EOQ) garmen pada tahun 2012 untuk setiap

kali pesan diperoleh dengan menggunakan rumus 1:

$$
\begin{aligned}
& E O Q=\sqrt{\frac{2(582.064,252)(13.832 .649,728}{13.522 .726,281}} \\
& E O Q=1.091,242(1.092)
\end{aligned}
$$

Jadi, siklus pemesanan ulang garmen pada tahun 2012 dengan model EOQ menggunakan rumus 2 :

$$
\begin{aligned}
\mathrm{F} & =\frac{D}{E O Q}=\frac{582.064,252}{1.091,242} \\
& =533,396(534 \mathrm{kali} / \text { tahun })
\end{aligned}
$$

Perhitungan Jumlah Produksi dengan Metode EPQ (Ekonomic Production Quantity) Jumlah produksi optimal garmen pada tahun 2011 dengan menggunakan metode EPQ untuk 1 tahun dengan menggunakan rumus 3 : $E P Q=\sqrt{\frac{2(581.541,867)(34.788 .738,577)(48.891,035)}{11.860 .666,197(48.891,035-48.461,822)}}$ $E P Q=19.712,807$ (19.713/produksi)

Jumlah produksi optimal garmen pada tahun 2012 dengan menggunakan metode EPQ untuk 1 tahun dengan menggunakan rumus 3:

$E P Q=\sqrt{\frac{2(582.064,252)(38.155 .309,780)(49.066,545)}{13.522 .724,281(49.066,545-48.505,354)}}$ $E P Q=16.946,626(16.947 /$ produksi $)$

Persediaan maksimal garmen tahun pada tahun 2011 dengan rumus 4 yaitu : $\operatorname{Imax}=19.712,807(1-48.461,822 / 48.891,035)$ $\operatorname{Imax}=173,058$

Persediaan maksimal garmen pada tahun 2012 dengan rumus 5 yaitu :

$\operatorname{Imax}=16.946,626(1-48.505,354 / 49.066,545)$ $\operatorname{Imax}=193,824$

Dengan adanya hasil persediaan maksimal maka produksi berikutnya dapat dikendalikan sesuai dengan jumlah maksimal persediaan pada tahun sebelumnya. Atau 
diambil rata rata. Yaitu $(I \max 2011+\operatorname{Imax}$ 2012) $/ 2=(173,058+193,824) / 2=183,4412$ Produksi dan Persediaan maksimal tahun 2013 harus sebesar 183,4412.

\subsection{Use case diagram}

Usecase diagram adalah Sebuah Produksi logis yang mengambarkan sistem secara formal mewakili bagaimana bisnis berinteraksi dengan lingkunganya. Dalam use case diagram ini terdapat beberapa actor antara lain:

a. Produksi

Produksi bertugas mengelola data Perhitungan EPQ baru, data persediaan dan penjualan, proses perhitungan EPQ, proses Pengen dalian Produksi dan mengelola laporan :

b. Admin

Proses mengelola data Produksi Baru, Konfigurasi, Login dan laporan.

c. Pemimpin

Pemimpin bertugas untuk mengelola mengelola data user dan laporan rekap hasil. Berdasarkan data yang telah dilakukan pada PT. Indogarmen dapat dilihat dalam Gambar 1.

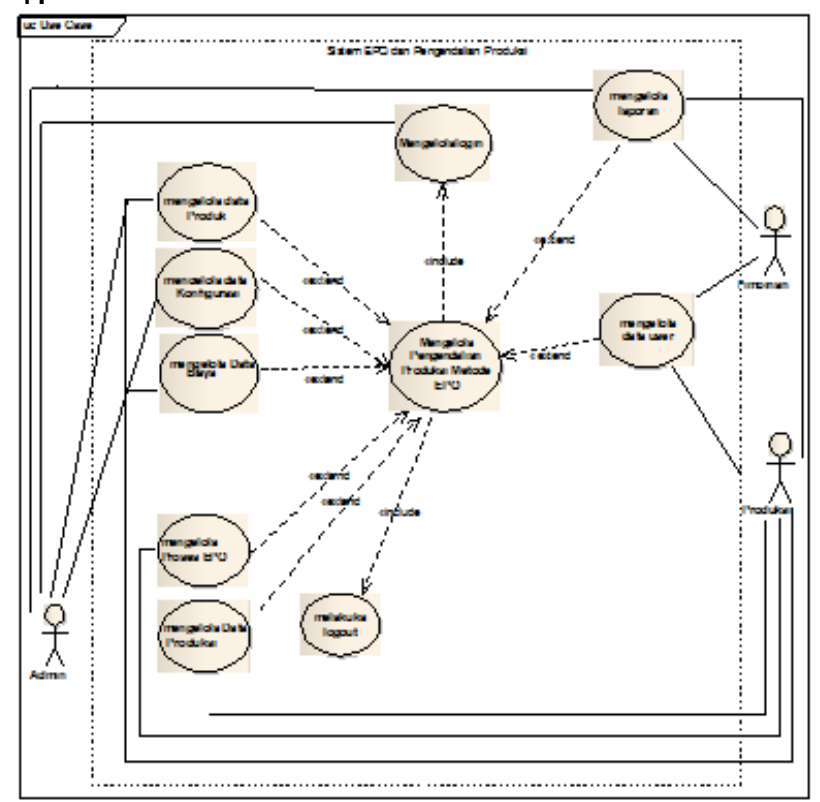

Gambar 1 use case diagram Penentuan EPQ Dan Pengendalian Produksi

\section{Use Case Realization Mengelola \\ Perhitungan EPQ}

Seperti tampak dalam Gambar 2. use case realization Perhitungan EPQ menggambarkan hubungan antara admin sebagai aktor pendata Perhitungan EPQ dengan sistem dalam menginputkan sebuah password yang dapat digunakan untuk login ke system.

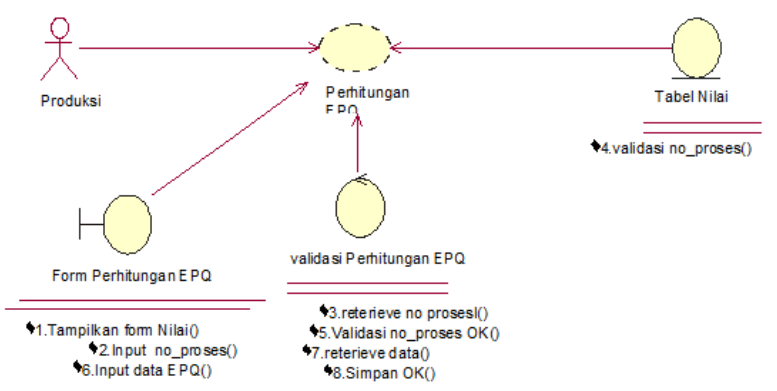

Gambar 2 Use Case Realization Mengelola Perhitungan EPQ

\subsection{Class diagram}

Class adalah sebuah spesifikasi yang jika di instansi terkait akan menghasilkan sebuah objek dan merupakan inti dari pengembangan dan desain berorientasi objek. Class menggambarkan keadaan (atribut/properti) suatu sistem, sekaligus menawarkan layanan untuk memanipulasi keadaan tersebut (metoda/fungsi). Dapat dilihat pada Gambar 3.

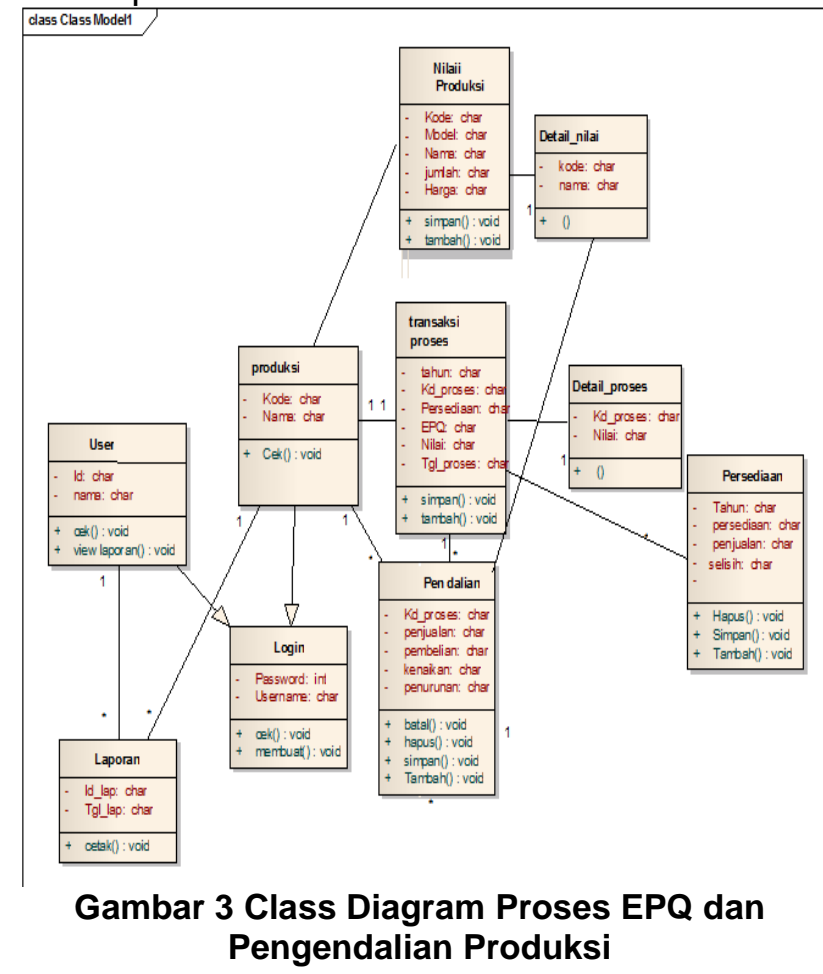

\subsection{Activity Diagram}

Activity diagram mengelola Perhitungan EPQ. Seorang user (Produksi) akan mengakses sistem kemudian sistem akan membawa user pada menu utama. Setelah tampilan menu utama keluar user akan memilih menu proses Perhitungan EPQ. Hal ini dapat dilihat pada Gambar 4 berikut. 


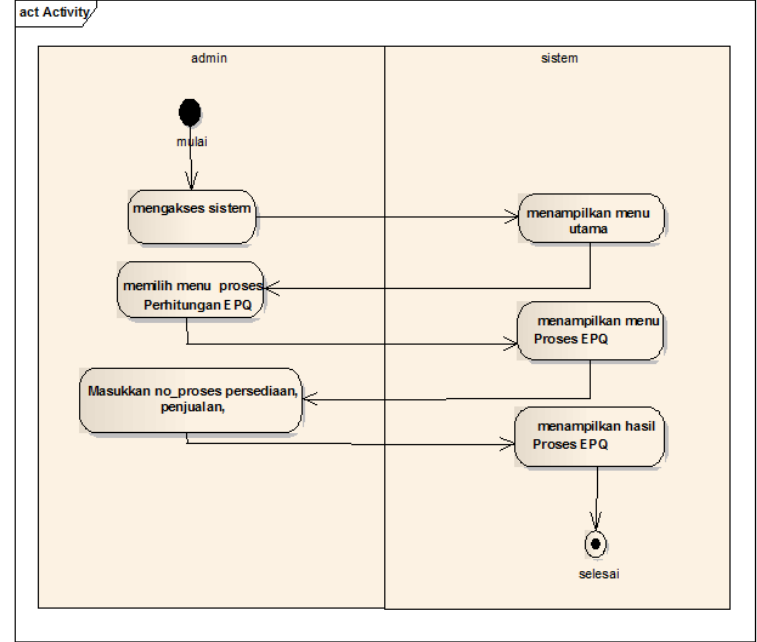

Gambar 4 Activity diagram menu proses Perhitungan EPQ.

\subsection{Interaction Sequence Diagram}

Interaction sequence diagram Transaksi Proses Pengendalian Produksi

Prosedur proses Pengendalian Produksi adalah sebagai berikut :

Bagian proses Pen dalian Produksi mengakses sistem dengan memilih menu Transaksi pada menu utama, kemudian pilih Transaksi Proses Pen dalian Produksi, setelah itu sistem akan menampilkan menu melakukan transaksi proses Pen dalian Produksi. Tahap selanjutnya adalah mengisi data Persediaan yang sudah masuk (set no_proses, tgl_proses, no_Persediaan, nama, nilai1, nilai2, nilai3).. hal ini dapat dilihat pada Gambar 5 berikut .

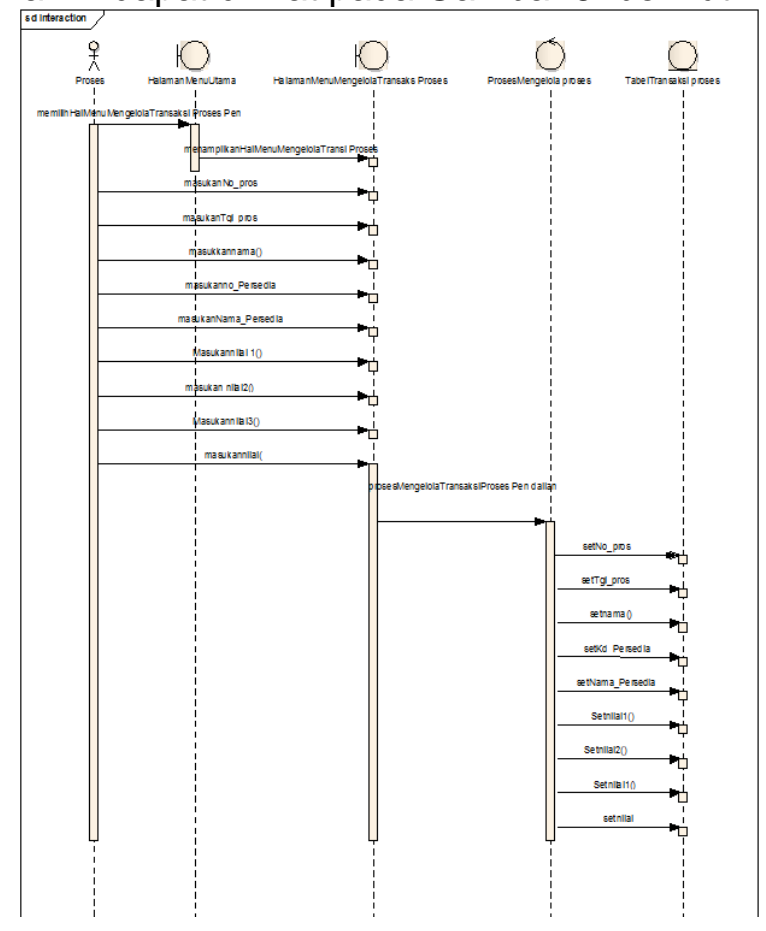

Gambar 5 Sequence diagram Transaksi Proses Pengendalian Produksi

\subsection{Uji Validitas}

Pengujian program digunakan untuk mengetahui Sistem Pendukung Keputusan valid atau tidak. Pengujian validitas program dilakukan dengan membandingkan hasil perhitungan Sistem Pendukung Keputusan dengan hasil perhitungan manual berdasarkan perhitungan di bab IV dengan Aplikasi di peroleh dari Implementasi Program yang telah dibuat. Sehingga dapat diketahui tingkat akurasi Sistem Pendukung Keputusan.

Hasil Pengujian EPQ Secara Manual

Persediaan maksimal garmen pada tahun 2011 yaitu :

$$
\begin{aligned}
& \operatorname{Imax}=E P Q(1-d / p) \\
& \operatorname{Imax}=19.712,807(1-8.461,822 / 48.891,035) \\
& \operatorname{Imax}=173,058
\end{aligned}
$$

Persediaan maksimal garmen pada tahun 2012 yaitu :

$$
\begin{aligned}
& \operatorname{Imax}=\mathrm{EPQ}(1-\mathrm{d} / \mathrm{p}) \\
& \operatorname{Imax}=16.946,626(1-48.505,354 / 49.066,545) \\
& \operatorname{Imax}=193,824 \\
& \text { Hasil ini dapat dilihat dalam Tabel } 3 .
\end{aligned}
$$

Tabel 3 Hasil Pengujian validitas Manual dengan Aplikasi

\begin{tabular}{|c|c|c|c|}
\hline Nama & $\begin{array}{c}\text { Pehitungan } \\
\text { manual }\end{array}$ & $\begin{array}{c}\text { Perhitungan } \\
\text { Metode EPQ }\end{array}$ & Kesimpulan \\
\hline Produksi 1 & 173,058 & 173 & Valid \\
\hline Produksi 2 & 193,824 & 193 & Valid \\
\hline
\end{tabular}

Hasil uji diatas dapat disimpulkan bahwa perangkat lunak yang dibangun bebas dari kesalahan sintaks dan secara fungsional mengeluarkan hasil yang sesuai dengan yang diharapkan. Semua fungsi pada aplikasi dapat berjalan dengan baik.

\section{PENUTUP}

\subsection{Kesimpulan}

Berdasarkan

menyimpulkan tujuan

Penulis bahwa pembuatan Pengendalian Produksi ini sistem yang diuji akan menghasilkan informasi data produksi dan proses perhitungan sehingga menghasilkan suatu model baru yang dapat meningkatkan sirkulasi produk. Dari proses yang terjadi menghasilkan hasil persediaan maksimal maka produksi berikutnya dapat dikendalikan sesuai dengan jumlah maksimal persediaan pada tahun sebelumnya. Atau diambil rata rata. Yaitu $(I \max 2011+I \max$ 2012) $/ 2=(173,058+193,824) / 2=183,4412$ 


\subsection{Saran}

Dalam era global sekarang ini sudah selayaknya mengembangkan proses pengelolaan produksi, diharapkan akan adanya suatu terobosan baru sistem pola produksi dan metode pengendalian produksi dengan sistem audit untuk lebih mematangkan kinerja produksi pada perusahaan.

\section{DAFTAR PUSTAKA}

[1] B. Senator Nur, Sistem Inventori. Bandung: Departemen Teknik Industri Institut Teknologi Bandung, 2003.

[2] E. Fibriani, D. Cahyadi, and A. Farid H, "Model Economic Production Quantity (EPQ) dengan Sinkronisasi Demand Kontinu Dan Demand Diskrit pada Produksi Kerupuk Ikan Sungai Khas Kalimantan Timur," JST (Jurnal Sains Ter., vol. 4, no. 1, p. 1, 2018.

[3] A. Widayanti and S. Si, "Aplikasi Perhitungan Jumlah Pesanan Produksi dan Frekuensi Produksi per Tahun dengan Metode Economic Production Quantity," vol. 2, no. 2, pp. 661-665, 2016.

[4] M. N. A. dwi Nurul izzahati, Dwi Eko Wahyono, "Program Teknik Industri Universitas Dian Nuswantoro." pp. 5-8, 2007.

[5] W. Prabowo P, Pemodelan Sistem Berorientasi Obyek dengan UML. Yogyakarta: Ghraha IImu, 2011.

[6] A. Nugroho, Rekayasa Perangkat Lunak Berbasis Objek dengan Metode USDP. Yogyakarta: Andy Offset, 2010. 